\title{
ВПЛИВ ПЕПТИДІВ НА СТАН ІМУННОЇ СИСТЕМИ ОРГАНІЗМУ ТА ВМІСТ БІЛКОВИХ ФРАКЦЙ КРОВІ ЩУРІВ, УРАЖЕНИХ СОЛЯМИ ВАЖКИХ МЕТАЛІВ І РАУНДАПОМ
}

Вступ. Свинець, як і всі важкі метали, - протоплазматична отрута широкого спектра дії, що викликає зміни в нервовій, серцево-судинній системах та крові. Він порушує фрерментативні реакції і знижує імунобіологічну резистентність організму. В організмі іони свинцю гальмують гуморальну імунну відповідь, що проявляється низьким продукуванням антитіл та імуноглобулінів класів $M, E, A$, збільшенням частоти респіраторних захворювань в осіб, уражених сполуками Плюмбуму.

Мета дослідження - вивчити вплив пептиду цистеїл-гістидил-тирозил-гістидил-ізолейцину на стан імунної системи та вміст білкових фрракцій у сироватці крові щурів різного віку з хронічним токсикозом, викликаним важкими металами і гліфосатом.

Методи дослідження. Досліди проводили на лабораторних нелінійних білих щурах-самцях трьох вікових груп: статевого дозрівання, статевої зрілості й старих тваринах, яким внутрішньошлунково протягом 30 днів вводили водні розчини Плюмбум ацетату, Купрум сульфату, гліфросату (у фрормі гербіциду раундапу). 3 метою корекції на 21 день через 6 год після введення токсикантів протягом 10 днів вводили пептид цистеїл-гістидил-тирозил-гістидил-ізолейцин. Стан імунної системи оцінювали за рівнем імуноглобулінів класів A, M, G та циркулюючих імунних комплексів у сироватці крові щурів.

Результати й обговорення. Встановлено, що в інтактних тварин і щурів при комбінованій дії Плюмбум ацетату, Купрум сульфрату і гліфосату (у фрормі гербіциду раундапу) з віком підвищувалась концентрація циркулюючих імунних комплексів та імуноглобулінів у сироватці крові. Введення пептиду призводило до часткового відновлення співвідношення білкових фрракцій у сироватці крові щурів та вмісту імуноглобулінів.

Висновок. Використання пептиду як чинника корекції частково нормалізує стан імунної системи та співвідношення білкових фрракцій у сироватці крові щурів із токсикозом, викликаним Плюмбум ацетатом, Купрум сульфратом і раундапом.

КЛЮчОВІ СЛОВА: імунна система; імуноглобуліни; білкові фракції;, Плюмбум ацетат; Купрум сульфрат; гліфосат.

ВСТУП. Відомо, що, потрапляючи в клітини, свинець, мідь та їх сполуки, як і багато інших важких металів, дезактивують фрерменти за рахунок зв'язування із сульфгідрильними групами білкової складової фрерментів і утворення -S-Pb-S-, S-Cu-S-комплексів. Вони здатні порушувати фрункції клітинних мембран шляхом стимулювання в них генерації активних фрорм Оксигену і вільнорадикальних процесів [1]. Свинець, потрапляючи в організм, уповільнює пізнавальний та інтелектуальний розвиток дітей, збільшує кров'яний тиск, викликає серцево-судинні захворювання в дорослих, фрункціональні порушення нервової системи, що супроводжуються головним болем, запамороченням, підвищеною стомлюваністю, дратівливістю, порушен(c) М. М. Корда, Є. Б. Дмухальська, Т. Я. Ярошенко, 2018. ням сну, погіршенням пам'яті, м'язовою гіпотонією, пітливістю. Свинець може замінювати кальцій у кістках, стаючи постійним джерелом отруєння. Органічні сполуки свинцю ще більш токсичні.

Мідь $€$ одним із незамінних мікроелементів для людини і тварин, водночас підвищення концентрації іонів міді у навколишньому середовищі може спричинити прояви гострої та хронічної токсичності. Антропогенними джерелами міді $є$ промислові відходи, стічні води підприємств кольорової металургії, добрива та пестициди, які містять мідь, паливо. Надмірна кількість іонів Купруму викликає такі ж зміни в організмі, як і дія сполук Плюмбуму. Солі Купруму підвищують проникність мітохондріальних мембран, руйнують еритроцити, спричиняють розлади нервової 
системи, нирок та печінки, знижують імунобіологічну реактивність [2]. Не менш токсичними $є$ фоссророрганічні пестициди, що впливають на нервову, м'язову та інші системи [3]. При отруєннях цими сполуками в медицині для зниження їх токсичної дії використовують антидоти. 3 літературних джерел відомо, що вільні амінокислоти та низькомолекулярні пептиди утворюють комплекси з іонами металів, особливо перехідних (d-елементів) [1]. Тому метою дослідження було вивчити вплив пептиду цистеїл-гістидил-тирозил-гістидил-ізолейцину на стан імунної системи та вміст білкових фрракцій у сироватці крові щурів різного віку з хронічним токсикозом, викликаним важкими металами і гліфросатом.

МЕТОДИ ДОСЛІДЖЕННЯ. 3 метою вивчення стану імунної системи організму за комбінованої дії Плюмбум ацетату, Купрум сульфату, раундапу використовували лабораторних нелінійних білих щурів-самців трьох вікових періодів: статевонезрілих (молодих масою 70-90 г і віком 1-3 місяці), статевозрілих (дорослих масою 170-210 г і віком 5-8 місяців), старих (масою 250-300 г і віком 20-24 місяці). Вік тварин визначали за схемою В. І. Махінько та В. М. Нікітіна [4].

Інтоксикацію в щурів моделювали шляхом одночасного щоденного перорального введення впродовж 30 діб водних розчинів Плюмбум ацетату в дозі 11 мг/кг маси тіла (1/20 LD 50 , Купрум сульсрату в дозі 13 мг/кг маси тіла $\left(1 / 20 \mathrm{LD}_{50}\right)$, глісросату (у фрормі гербіциду раундапу) в дозі 250 мг/кг маси тіла (1/20 LD $\left.{ }_{50}\right)$. Як контроль використовували інтактних тварин відповідного віку, яким вводили питну водопровідну дехлоровану воду. 3 метою корекції виявлених порушень на 21 день експерименту через 6 год після введення токсикантів щодня протягом 10 днів вводили внутрішньошлунково пептид цистеїл-гістидил-тирозил-гістидил-ізолейцин у дозі 9 мг/кг маси тіла (концентрація амінокислот у крові).

Усіх піддослідних тварин було поділено на такі групи: 1-ша - інтактні (контрольні); 2-га щури, одночасно уражені всіма вищеперерахованими токсикантами; 3-тя - тварини, яким проводили корекцію пептидом. На 31 добу після останнього введення ксенобіотиків та чинників корекції щурів виводили з експерименту за умов тіопентал-натрієвого наркозу.

Під час виконання досліджень усі тварини перебували у віварії Тернопільського державного медичного університету імені І. Я. Горбачевського на стандартному раціоні відповідно до санітарно-гігієнічних норм. Утримували щурів і проводили всі експерименти на них із дотриманням національних (Закон України № 3447-IV
“Про захист тварин від жорстокої поведінки", 2006) та міжнародних (Європейська конвенція про захист хребетних тварин, що використовуються для дослідних та інших наукових цілей, Страсбург, 1986) загальних правил і рекомендацій щодо гуманного поводження з лабораторними тваринами [5-7].

Гуморальну ланку імунітету оцінювали за рівнем імуноглобулінів (Ig) класів A, M, G у сироватці крові біохімічним методом [8] та за кількістю циркулюючих імунних комплексів (ЦІК) у сироватці крові, які визначали шляхом преципітації їх розчином поліетиленгліколю-6000 [8].

Щоб дослідити білкові фрракції, використовували діагностичний набір для електрофоретичного розділення білків сироватки крові на агарозі "Cormay gel protein 100" виробництва фрірми "Cormay" (Австрія).

Статистичну обробку циоррових даних здійснювали за допомогою програмного забезпечення Excel ("Microsoft", США) і STATISTICA 6.0 ("Statsoft", США) з використанням непараметричних методів оцінки одержаних даних. Для всіх показників розраховували значення середньої арифрметичної вибірки (М), її дисперсії і помилки середньої (m). Достовірність різниці значень між незалежними кількісними величинами визначали за допомогою критерію Манна-Уїтні. Зміни вважали статистично достовірними при р<0,05 [9].

РЕЗУЛЬТАТИ Й ОБГОВОРЕННЯ. ВіДМічеНО, що $з$ віком знижується вміст альбумінів. Так, у дорослих інтактних тварин він зменшився на 5 \%, а в старих - на 8 \% порівняно з молодими щурами, що, очевидно, свідчить про зниження білоксинтезувальної фрункції печінки з віком. За дії досліджуваних ксенобіотиків ми спостерігали зменшення вмісту альбумінів у плазмі крові тварин усіх вікових періодів: у молодих - на $18 \%$, у дорослих - на $10 \%$, у старих - на $24 \%$ щодо контролю (табл. 1).

У молодих і старих тварин спостерігали тенденцію до зростання концентрації $\alpha_{1}^{-}, \alpha_{2}-$, $\beta$-глобулінів та зниження вмісту фракцій у-глобулінів порівняно $з$ контрольною групою (табл. 1). Так, концентрація $\alpha_{1}^{-}, \alpha_{2}-$ та $\beta$-глобулінів у сироватці крові щурів за комбінованого впливу раундапу, Купрум сульфату і Плюмбум ацетату підвищилася, відповідно, у 2,0, 1,8 та 1,3 раза від рівня інтактних тварин. Щодо у-глобулінів, то їх вміст достовірно зменшився на 19 \% порівняно 3 контролем.

У дорослих щурів після ураження токсикантами була дещо інша спрямованість змін у перерозподілі білкових фрракцій на електрофореграмах. Концентрація фрракцій $\beta$ - і у-глобулінів знизилася на 19 та 28 \% порівняно 3 контроль- 
Таблиця 1 - Співвідношення білкових фракцій у сироватці крові щурів різних вікових періодів за дії Плюмбум ацетату (M $\pm m, n=10)$

\begin{tabular}{|c|c|c|c|c|c|}
\hline \multirow{2}{*}{$\begin{array}{c}\text { Віковий період } \\
\text { тварин }\end{array}$} & \multirow{2}{*}{\multicolumn{2}{|c|}{ Показник }} & \multicolumn{3}{|c|}{ Група тварин } \\
\hline & & & інтактні & уражені & кориговані пептидом \\
\hline \multirow[t]{6}{*}{ Молоді } & \multicolumn{2}{|c|}{ Альбуміни, \% } & $57,67 \pm 1,36$ & $43,85 \pm 0,52^{*}$ & $56,48 \pm 0,63$ \\
\hline & \multirow{4}{*}{$\begin{array}{c}\text { Глобуліни, } \\
\%\end{array}$} & $\alpha_{1}$-глобуліни & $6,09 \pm 0,42$ & $12,37 \pm 0,20$ * & $6,73 \pm 0,21$ \\
\hline & & $\alpha_{2}$-глобуліни & $8,17 \pm 0,36$ & $14,39 \pm 0,31^{*}$ & $8,75 \pm 0,21^{* \star}$ \\
\hline & & $\beta$-глобуліни & $13,01 \pm 0,18$ & $16,68 \pm 0,32^{*}$ & $14,10 \pm 0,35$ \\
\hline & & у-глобуліни & $15,06 \pm 0,4$ & $12,33 \pm 0,37^{*}$ & $14,51 \pm 0,30$ ** \\
\hline & \multicolumn{2}{|c|}{ А/Г коефріцієнт } & 1,36 & 0,78 & $1,29 * \star$ \\
\hline \multirow[t]{6}{*}{ Дорослі } & \multicolumn{2}{|c|}{ Альбуміни, \% } & $53,77 \pm 1,36$ & $46,11 \pm 0,48^{*}$ & $52,40 \pm 0,63^{\star \star}$ \\
\hline & \multirow{4}{*}{$\begin{array}{c}\text { Глобуліни, } \\
\%\end{array}$} & $\alpha_{1}$-глобуліни & $7,88 \pm 0,30$ & $13,75 \pm 0,21$ & $8,34 \pm 0,17^{\star \star}$ \\
\hline & & $\alpha_{2}$-глобуліни & $7,82 \pm 0,14$ & $15,74 \pm 0,28 *$ & $8,31 \pm 0,25$ \\
\hline & & ß-глобуліни & $13,90 \pm 0,45$ & $12,58 \pm 0,35^{\star}$ & $14,30 \pm 0,19 * \star$ \\
\hline & & ү-глобуліни & $16,33 \pm 0,33$ & $11,81 \pm 0,21$ & $15,71 \pm 0,19$ \\
\hline & \multicolumn{2}{|c|}{ А/Г коефріцієнт } & 1,16 & 0,86 & 1,10 \\
\hline \multirow[t]{6}{*}{ Старі } & \multicolumn{2}{|c|}{ Альбуміни, \% } & $48,39 \pm 0,74$ & $37,05 \pm 0,50$ * & $46,58 \pm 0,64^{\star \star}$ \\
\hline & \multirow{4}{*}{$\begin{array}{c}\text { Глобуліни, } \\
\%\end{array}$} & $\alpha_{1}$-глобуліни & $9,66 \pm 0,25$ & $15,52 \pm 0,26$ & $10,03 \pm 0,18$ \\
\hline & & $\alpha_{2}$-глобуліни & $10,49 \pm 0,26$ & $16,16 \pm 0,43$ & $11,09 \pm 0,27^{\star \star}$ \\
\hline & & $\beta$-глобуліни & $14,81 \pm 0,15$ & $18,99 \pm 0,32^{*}$ & $15,45 \pm 0,27^{\star *}$ \\
\hline & & у-глобуліни & $15,88 \pm 0,35$ & $12,28 \pm 0,23^{*}$ & $14,84 \pm 0,23^{*}$ \\
\hline & \multicolumn{2}{|c|}{ А/Г коефріцієнт } & 0,94 & 0,59 & 0,87 \\
\hline
\end{tabular}

Примітки. Тут і в таблиці 2:

1. * - результати достовірні відносно інтактних тварин $(p<0,05)$.

2. ** - результати достовірні відносно показників у щурів за комбінованого ураження $(p<0,05)$.

ною групою. Концентрація $\alpha_{1}$ - та $\alpha_{2}$-глобулінів зросла на 75 ( $\alpha_{1}$-глобуліни) і $100 \%$ ( $\alpha_{2}$-глобуліни) від рівня інтактних тварин.

У старих щурів зміни в білкових фрракціях такі ж, яку молодих. Так, вміст $\alpha_{1}$-, $\alpha_{2}$ - та $\beta$-глобулінів достовірно збільшився, відповідно, на 60, 82 і $28 \%$ від рівня інтактних тварин; концентрація у-глобулінів зменшилася на 27 \% порівняно 3 контролем.

Фракція у-глобулінів складається з імуноглобулінів класів A, M, G, E, які функціонально $\epsilon$ антитілами, що забезпечують гуморальний імунітет. Зниження вмісту в крові у-глобулінів $€$ одним з основних критеріїв, які вказують на пригнічення гуморального імунітету за дії солей Плюмбуму і Купруму, глісросату. Це свідчить про те, що знизився синтез імунних білків - імуноглобулінів у відповідь на патологічний процес в організмі, спричинений інтоксикацією.

Відомо, що співвідношення між різними класами білкових структур у сироватці крові відображає стан організму. Альбуміновий коефріцієнт (співвідношення між кількістю альбумінів і сумою глобулінів) є показником стану білкового обміну в організмі. Низькі значення цього показника вказують на зростання катаболізму білків.

Як видно 3 таблиці 1, з віком у інтактних щурів альбуміновий коефріцієнт знижувався і становив для статевозрілих 85 \%, для старих 69 \% від даного показника статевонезрілих тварин. В уражених щурів усіх вікових періодів різко зменшувався білковий коефіцієнт порівняно з таким у здорових тварин, і для молодих щурів він становив $57 \%$, дорослих - $74 \%$, старих $-63 \%$ порівняно $з$ контролем. Отже, вказані зміни співвідношення білкових срракцій у крові щурів свідчать про сповільнення синтезу альбумінів у печінці, імунну реакцію організму на дію раундапу, Плюмбум ацетату, Купрум сульсрату.

Наведені вище результати наших досліджень вказують на те, що, поряд із змінами розподілу та вмісту білкових срракцій, відбуваються зміни стану імунної системи. На вікові особливості фрункціонування імунної системи впливають як екзо-, так і ендогенні чинники [10]. Результати наших досліджень показали, що в інтактних тварин 3 віком підвищувалась концентрація циркулюючих імунних комплексів та імуноглобулінів (табл. 2). Так, вміст циркулюючих імунних комплексів у крові дорослих щурів збільшився на $40 \%$, а в старих - на 65 \% порівняно з молодими тваринами. Такуж тенденцію спостерігали при аналізі концентрації імуноглобулінів. За комбінованої дії всіх ксенобіотиків цей показник підвищився: у статевонезрілих тварин - на 96 \%, у статевозрілих - на $42 \%$, у старих - на $68 \%$ порівняно 3 контролем.

При аналізі комбінованого впливу солей важких металів і раундапу на концентрацію імуноглобулінів ми спостерігали зменшення цих показників у тварин усіх вікових періодів. Так, за дії раундапу, Купрум сульсрату і Плюмбум ацетату концентрація імуноглобулінів у сироватці крові молодих щурів знизилася: класу А - на $38 \%$, класу G - на $32 \%$, класу М - на $25 \%$. 
Таблиця 2 - Показники гуморального імунітету в сироватці крові щурів різного віку, уражених

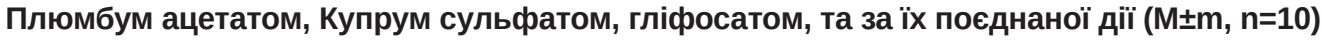

\begin{tabular}{|c|c|c|c|c|}
\hline \multirow{2}{*}{ Віковий період тварин } & \multirow{2}{*}{ Показник } & \multicolumn{3}{|c|}{ Група тварин } \\
\hline & & інтактні & уражені & кориговані пептидом \\
\hline \multirow[t]{4}{*}{ Статевонезрілі } & ЦІК, ум. од./л & $33,6 \pm 2,1$ & $65,8 \pm 2,4^{*}$ & $37,4 \pm 1,8^{\star \star}$ \\
\hline & $\lg \mathrm{A}$, г/л & $1,13 \pm 0,04$ & $0,70 \pm 0,01^{*}$ & $0,99 \pm 0,02$ \\
\hline & $\operatorname{lgG}$, г/л & $4,19 \pm 0,09$ & $2,85 \pm 0,03^{*}$ & $3,98 \pm 0,02$ \\
\hline & $\lg \mathrm{M}$, г/л & $8,58 \pm 0,08$ & $6,64 \pm 0,07^{*}$ & $7,91 \pm 0,07^{\star \star}$ \\
\hline \multirow[t]{4}{*}{ Статевозрілі } & ЦІК, ум. од./л & $47,1 \pm 2,0$ & $66,8 \pm 3,4^{*}$ & $49,2 \pm 1,8^{\star \star}$ \\
\hline & $\lg \mathrm{A}$, г/л & $2,04 \pm 0,03$ & $1,84 \pm 0,02^{*}$ & $1,97 \pm 0,02^{\star \star}$ \\
\hline & $\operatorname{lgG}$, г/л & $5,41 \pm 0,08$ & $4,28 \pm 0,05$ & $5,31 \pm 0,04$ ** \\
\hline & $\operatorname{lgM}$, г/л & $9,82 \pm 0,10$ & $7,94 \pm 0,12^{*}$ & $9,10 \pm 0,09 * \star$ \\
\hline \multirow[t]{4}{*}{ Старі } & ЦІК, ум. од./л & $55,7 \pm 2,0$ & $93,3 \pm 2,8^{*}$ & $61,7 \pm 1,8^{\star \star}$ \\
\hline & $\lg \mathrm{A}$, г/л & $2,89 \pm 0.04$ & $1,92 \pm 0.02^{*}$ & $2,61 \pm 0,02^{\star \star}$ \\
\hline & $\operatorname{lgG}$, г/л & $6,08 \pm 0,02$ & $4,27 \pm 0,07^{*}$ & $5,94 \pm 0,08$ \\
\hline & $\lg$, г/л & $10,67 \pm 0,11$ & $7,21 \pm 0,10$ & $9,69 \pm 0,14$ \\
\hline
\end{tabular}

Введення щурам пептиду цистеїл-гістидил-тирозил-гістидил-ізолейцину призвело до зменшення в сторону норми вмісту циркулюючих імунних комплексів у тварин усіх вікових періодів: у сироватці крові щурів молодого віку він знизився на $43 \%$, а в дорослих і старих - на 28 та $44 \%$ відповідно порівняно з ураженими тваринами. Використання пептиду як чинника корекції сприяло відновленню співвідношення білкових фрракцій. Кращий коригувальний ефрект пептиду ми спостерігали в молодих тварин. Так, вміст альбумінів і ү-глобулінів зріс на $15 \%$ від рівня уражених щурів, а концентрація $\alpha_{1}^{-}, \alpha_{2}$ - та $\beta$-глобулінів знизилася на 46, 39 і $16 \%$ відповідно від рівня уражених тварин.

Аналізуючи дані наших досліджень, можемо вважати, що використані токсиканти пригнічують гуморальну ланку імунітету у тварин усіх вікових періодів, особливо молодого віку, в яких ще недостатньо сорормована імунна система. Введення пептиду частково відновлює вміст імуногло-

\section{СПИСОК ЛІТЕРАТУРИ}

1. К клинике и лечению неврологических и абдоминальных нарушений при хронической свинцовой интоксикации / Г. М. Балан, И.В.Юрченко, Л.В.Игнатенко [и др.] // Совр. пробл. токсикол. - 2003. - № 4. C. $50-56$.

2. Трахтенберг И. М. Книга о ядах и отравлениях / И. М. Трахтенберг. - К. : Наукова думка, 2000. - 366 с.

3. Soundbite molecules / Cotton Simon // Education in Chemistry. - 2005. - 42, No. 2. - P. 34. - Mode access : http://www.rsc.org/Education/EiC/issues.

4. Махинько В. И. Константы роста и фрункциональные периоды развития в постнатальной жизни булінів, циркулюючих імунних комплексів, співвідношення білкових фрракцій у сироватці крові щурів.

ВИСНОВКИ. 1. За комбінованої дії раундапу, Плюмбум ацетату, Купрум сульфрату відбувається перерозподіл білкових срракцій у сироватці крові щурів: знижується вміст альбумінів на фроні зростання концентрації глобулінів.

2. За дії ксенобіотиків підвищується вміст циркулюючих імунних комплексів, знижується вміст імуноглобулінів усіх класів.

3. Введення ураженим тваринам пептиду цистеїл-гістидил-тирозил-гістидил-ізолейцину сприяє частковому відновленню співвідношення вмісту білкових структур у сироватці крові щурів і стану імунної системи організму тварин.

Перспективи подальших досліджень. Плануємо визначити вплив пептидів на стан антиоксидантної системи та білковий обмін у щурів за комплексної дії Купрум сульсрату, Плюмбум ацетату і раундапу.

белых крыс / В. И. Махинько, В. Н. Никитин // Молекулярные и фризиологические механизмы возрастного развития. - К., 1975. - С. 308-326.

5. Про захист тварин від жорстокого поводження : Закон України від 21.02.2006 р. № 3447.

6. Науково-практичні рекомендації з утримання лабораторних тварин та роботи з ними / Ю. М. Кожем'якін, О. С. Хромов, М. А. Філоненко, Г. А. Сайфретдінова. - К. : Авіцена, 2002. - 156 с.

7. European convention for the protection of vertebrate animals used for experimental and other scientific purposes. - Council of Europe. Strasbourg, 1986. No. 123. -52 p. 
8. Кишкун А. А. Иммунологические исследования и методы диагностики инсекционных заболеваний в клинической практике / А. А. Кишкун. - М. : МИА, 2009. - 712 c.

\section{REFERENCES}

1. Balan, G.M., Yurchenko, I.V., \& Ignatenko, L.V. (2003). K klinike i lecheniyu nevrologicheskikh i abdominalnykh narusheniy pri khronicheskoy svintsovoy intoksikatsii [Clinic and treatment of neurological and abdominal disorders in chronic lead intoxication]. Sovr. probl. toksikol. - Modern Problems of Toxicology, 4, 5056 [in Russian].

2. Trakhtenberg, I.M. (2000). Kniga o yadakh i otravleniyakh [The book on poisons and poisoning]. Kyiv: Naukova dumka [in Russian].

3. Cotton Simon. (2005). Soundbite molecules. Education in Chemistry, 42 (2), 34. Retrieved from: http:// www.rsc.org/Education/EiC/issues.

4. Mahinko, V.I., \& Nikitin, V.N. (1975). Konstanty rosta i funktsionalnye periody razvitiya $v$ postnatalnoy zhizni belykh krys [Growth constants and functional periods of development in the postnatal life of white rats]. Molekulyarnyye i fiziologicheskiye mekhanizmy vozrastnogo razvitiya - Molecular and physiological mechanisms of age development [in Russian].

5. Zakon Ukrainy "Pro zakhyst tvaryn vid zhorstokoho povodzhennia" vid 21.02.2006 r., № 3447 [The Law
9. Bernard Rosner. Fundamentals of Biostatistics. Boston, USA. - 2010. - 859 p.

10. Система цитокинов. Теоретические и клинические аспекты / под ред. В. А. Козлова, С. В. Сенникова. - Новосибирск : Наука, 2004. - 344 с.

of Ukraine "On the Protection of animals from ill-treatment" of 02.21. 2006, No. 3447] [in Ukrainian].

6. Kozhemiakin, Yu.M., Khromova, O.S., \& Filonenko, M.A. (2002). Naukovo-praktychni rekomendatsii z utrymannia laboratornykh tvaryn ta robota z nymy [Scientific and practical recommendations for the maintenance of laboratory animals and work with them]. Kyiv: Avitsena [in Ukrainian].

7. (1986). European convention for the protection of vertebrate animals used for experimental and other scientific purposes. - Council of Europe. Strasbourg.

8. Kishkun, A.A. (2009). Immunologicheskie issledovaniya i metody diagnostiki infektsionnykh zabolevaniy $v$ klinicheskoy praktike [Immunological studies and methods for the diagnosis of infectious diseases in clinical practice]. Moscow: MIA [in Russian].

9. Bernard Rosner. (2010). Fundamentals of biostatistics. Boston; USA.

10. Kozlov, V.A., \& Sennikov, S.V. (Eds.). (2004). Sistema tsitokinov. Teoreticheskiye i klinicheskiye aspekty [Cytokine system. Theoretical and clinical aspects]. Novosibirsk: Nauka [in Russian].

\section{ВЛИЯНИЕ ПЕПТИДОВ НА СОСТОЯНИЕ ИММУННОЙ СИСТЕМЫ ОРГАНИЗМА И СОДЕРЖАНИЕ БЕЛКОВЫХ ФРАКЦИЙ КРОВИ КРЫС, ПОРАЖЕННЫХ СОЛЯМИ ТЯЖЕЛЫХ МЕТАЛЛОВ И РАУНДАПОМ}

\section{Резюме}

Вступление. Свинец, как и все тяжелые металлы, - протоплазматический яд широкого спектра действия, который вызывает изменения в нервной, сердечно-сосудистой системах и крови. Он нарушает фрерментативные реакции и снижает иммунобиологическую резистентность организма. В организме ионы свинца тормозят гуморальный иммунный ответ, что проявляется низким продуцированием антител и иммуноглобулинов классов $M, E, A$, увеличением частоты респираторных заболеваний у лиц, пораженных соединениями свинца.

Цель исследования - изучить влияние пептида цистеил-гистидил-тирозил-гистидил-изолейцина на состояние иммунной системы и содержание белковых фрракций в сыворотке крови крыс разного возраста с хроническим токсикозом, вызванным тяжелыми металлами и глифросатом.

Методы исследования. Опыты проводили на лабораторных нелинейных белых крысах-самцах трех возрастных групп: полового созревания, половой зрелости и старых животных, которым внутрижелудочно в течение 30 дней вводили водные растворы ацетата свинца, сульфрата меди и глифосата (в 
фрорме гербицида раундапа). С целью коррекции на 21 день через 6 ч после введения токсикантов в течение 10 дней вводили пептид цистеил-гистидил-тирозил-гистидил-изолейцин. Состояние иммунной системы оценивали по уровню иммуноглобулинов классов $A, M, G$ и циркулирующих иммунных комплексов в сыворотке крови крыс.

Результаты и обсуждение. Установлено, что в интактных животных и крыс при комбинированном действии ацетата свинца, сульфрата меди и глифосата (в форме гербицида раундапа) с возрастом повышалась концентрация циркулирующих иммунных комплексов и иммуноглобулинов в сыворотке крови. Введение пептида приводило к частичному восстановлению соотношения белковых фрракций в сыворотке крови крыс и содержания иммуноглобулинов.

Вывод. Использование пептида как фрактора коррекции частично нормализует состояние иммунной системы и соотношение белковых фрракций в сыворотке крови крыс с токсикозом, вызванным ацетатом свинца, сульфратом меди и раундапом.

КЛЮЧЕВЫЕ СЛОВА: иммунная система; иммуноглобулины; ацетат свинца; сульфат меди; глифосат.

M. M. Korda, Ye. B. Dumukhalska, T. Ya. Yaroshenko I. HORBACHEVSKY TERNOPIL STATE MEDICAL UNIVERSITY

THE EFFECT OF PEPTIDES ON THE STATE OF IMMUNE SYSTEM OF THE BODY AND CONTENT OF PROTEIN FRACTIONS IN BLOOD OF RATS AFFLICTED BY SALTS OF HEAVY METALS AND ROUNDUP

\begin{abstract}
Summary
Introduction. Lead is a protoplasmic poison and has detrimental effects on the nervous, cardiovascular system and blood as all heavy metals. It violates enzymatic reactions, depress the immunobiological resistance of the body. Lead affects humoral immune response, that is impairment of antibody production, inhibits the production of $M, E$ and $A$ immunoglobulins classes and increases respiratory diseases frequency in people affected by Plumbum compounds.

The aim of the study - to reseach the effect of cystile-histidyl-tyrosyl-histidil-isoleucine peptide on the immune system state and content of protein fractions in blood serum in all ages rats with chronic toxicosis, heavy metals and glyphosate.

Research Methods. Experiments were carried out on laboratory nonlinear white male rats of three age groups: puberty, mature and old animals, which were injected intragastrically for 30 days with Plumbum acetate, Cuprum sulfate, glyphosate (in the form of a herbicide roundup). For the purpose of correction for 21 days 6 hours after the administration of the toxicants for 10 days, the cystile-hystidyl-tyrosyl-histidil-isoleucine peptide was injected. The state of the immune system was assessed by the level of A, M, G immunoglobulins and circulating immune complexes in the blood serum of rats.

Results and Discussion. It was established that in intact rats when combined action of Plumbum acetate, Cuprum sulfate, glyphosate (in the form of a herbicide roundup), the concentration of circulating immune complexes (CIC) and immunoglobulins in the blood serum of animals increased with age. The introduction of the peptide leads to partial restoration of the ratio of protein fractions in blood serum of rats and the content of immunoglobulins.

Conclusion. The use of the peptide as a correction factor partially normalizes the state of the immune system and the ratio of protein fractions in blood serum of rats with toxicosis caused by Plumbum acetate, Cuprum sulfate and the roundup.
\end{abstract}

KEY WORDS: immune system; immunoglobulins; protein's fractions; Plumbum acetate; Cuprum sulfate; glyphosate.

Отримано 19.07.18

Адреса для листування: Є. Б. Дмухальська, Тернопільський державний медичний університет імені І. Я. Горбачевського, майдан Волі, 1, Тернопіль, 46001, Україна, e-mail: dmukhalska@tdmu.edu.ua. 